\title{
Tradisi Massuru' dan Pertobatan Dalam Injil Sinoptik
}

\author{
Frans Paillin Rumbi \\ Sekolah Tinggi Agama Kristen Negeri Toraja \\ fransrumbi24@gmail.com
}

\begin{abstract}
This paper juxtaposes two models of wrong forgiveness and sin. Massuru 'in Toraja culture and repentance in the gospel. This research study is explanatory in order to explain the concept of masu suru and repentance from the theological roots that shape it. The materials used are sourced from the literature but in dialogue with the observations or experiences that the author has encountered in the field, both when observing the way the Toraja interpret their traditions and interpret liturgical confessions in the congregation. The results of this study found that massuru and repentance had a more or less the same basic pattern, which was initiated by false recognition or sin, forgiveness and finally peace. Another similarity is improving behavior, reestablishing relations with God and fellow creatures. But there are differences in terms of initiative, targets in the visible and inner aspects, atonement victims. Massuru 'can be used as a model for confession in congregations and repentant pastoral models, but it needs to adjust its meaning to the values of the contain of Christian teachings.
\end{abstract}

Keywords: massuru', synoptic gospels, sin, repentance, forgiveness

\begin{abstract}
Abstrak: Tulisan ini menyandingkan dua model pengampunan salah dan dosa. Massuru' dalam kebudayan Toraja dan pertobatan dalam Injil. Kajian penelitian ini bersifat eksplanasi untuk menjelaskan konsep massuru' dan pertobatan dari akar tradisi-teologis yang membentuknya. Bahan-bahan yang digunakan bersumber dari kepustakaan tetapi di dialogkan dengan pengamatan atau pengalaman yang selama ini penulis jumpai di lapangan, baik ketika mengamati cara orang Toraja memaknai tradisinya maupun memaknai liturgi pengakuan dosa dalam jemaat. Hasil penelitian ini menemukan bahwa massuru' dan pertobatan memiliki pola dasar yang kurang lebih sama, yakni dimulai dengan pengakuan salah atau dosa, pengampunan dan akhirnya perdamaian. Kesamaan lain yakni memperbaiki perilaku, membangun kembali relasi dengan Allah dan sesama ciptaan. Tetapi terdapat perbedaan dari segi inisiatif, sasaran pada aspek kelihatan dan batin, korban pendamaian. Massuru' dapat digunakan sebagai model akta pengakuan dosa dalam jemaat maupun model pastoral tobat, akan tetapi perlu menyesuaikan maknanya dengan nilai-nilai yang terkandung alam ajaran Kristen.
\end{abstract}

Kata-kata kunci: massuru,' injil sinoptik, dosa, pertobatan, pengampunan

\section{A. Pendahuluan}

Dari segi iman Kristen, kesucian (dapat juga dibaca: kekudusan) merupakan salah satu aspek yang dituntut Allah kepada manusia. Ketika Allah menetapkan kesucian sebagai salah satu syarat mempertahankan relasi denganNya, maka Ia 
menuntut manusia taat kepada nilai-nilai kehidupan sebagaimana yang diajarkan para nabi, rasul-rasul dan Yesus Kristus. Lebih dari itu, kesucian menandakan ungkapan syukur orang percaya atas anugerah keselamatan yang dinyatakan Allah.

Menjadi setia bukan sebuah perkara yang mudah sebab manusia harus hidup dalam komitmen. Seringkali kesulitan itu menjadi alasan pembenaran diri atas perilaku yang berlawanan dengan kehendak-Nya. Berhadapan dengan situasi itu, paham-paham religius yang ada mengarahkan manusia untuk memperbaharui diri dengan mengaku dosa, bertobat dan akhirnya menerima pengampunan. Dengan mengaku dosa, manusia mempunyai kesempatan memperbaiki relasi dengan Allah, memulai hidup baru serta menatanya. Dalam kondisi kedosaan, pertobatan harusnya menda-pat perhatian serius.

Pertobatan merupakan hasil dari kontemplasi, yang mendorong seseorang berbalik dari perilaku menyimpang lalu hidup sesuai dengan kehendak Allah. Ada beberapa cara mengungkapkan pertobatan, antara lain: Pertama, melalui pengakuan bersama seperti saat mengucapkan akta pengakuan dosa. Kedua, pengakuan pribadi sebagai bentuk penyesalan di hadapan Allah. Pertobatan mengandung pengakuan, komitmen serta bertindak dengan benar. Pertobatan mengarah pada ortopraksis.

Tantangan yang muncul dalam pelayanan gereja ialah akta pengakuan dosa seringkali tidak memberi perubahan pada cara hidup jemaat. Di jemaat berkembang pemahaman bahwa akta pengakuan dosa hanya salah satu dari liturgi, sehingga pengucapannya seringkali bersifat formalitas. Dalam konteks yang lain, pengakuan dosa merupakan respon atas berita pengampuan dosa dari Allah. Tetapi tidak dapat dipungkiri, praktiknya seringkali bersifat temporal. Maksudnya membawa perubahan sesaat karena setelah itu yang bersangkutan kembali melalukan kebiasan lama.

Idealnya pengakuan dosa menghasilkan pertobatan. Untuk mencapai hal tersebut, maka spiritualitas yang dikembangkan perlu disertai pengetahuan tentang makna pengakuan dosa, pertobatan serta pengampunan. Cara lain adalah mencari berbagai bentuk kearifan lokal yang dapat ditransformasi menjadi sarana memertahankan hidup. Pilihan itulah yang hendak saya uraikan. Sepengetahuan saya, sudah ada beberapa skripsi yang mengkaji massuru' dengan menggunakan pendekatan teologi sosiologis. Akan tetapi belum ada yang secara khusus menyandingkan tradisi massuru' dengan Injil Sinoptik.

Tradisi orang Toraja kurang mengenal dikotomi hidup suci dan dosa. Istilah dosa dikenal seiring dengan masuknya agama-agama dari luar. Corak spritualitas orang Toraja lebih berhubungan dengan konsep benar dan salah. Meski demikian, ada kesamaan mendasar antara konsep salah dan dosa yakni menuntut orang bertindak sesuai norma-norma yang diakui bersama.

Pengakuan salah dalam budaya Toraja dikenal dengan nama massuru,' yang dimaknai sebagai ritus penyucian atau pembersihan dari berbagai perilaku buruk akibat pelanggaran terhadap norma. Massuru' merupakan ritus pengakuan, pertobatan dan pengampunan salah, dilestarikan demi menjaga kesetiaan masyarakat kepada kepada norma-norma yang disepakati.

Saya terdorong mengkaji makna pengakuan salah dalam tradisi Toraja tentang massuru' yakni sebagai bagian dari sistem religius tradisional, yang tetap digunakan oleh umat Kristen dari berbagai wilayah Toraja sebagai cara menyelesaikan masalah. Beberapa pemahaman memperlihatkan massuru' berhasil memberi perubahan hidup, dibandingkan pengakuan dosa yang diucapkan di gereja ataupun siasat (disiplin) gerejawi. Mereka yang pernah dikenai sanksi massuru' atau bahkan mengetahui tindakan-tindakan yang dapat dikenai sanksi massuru' akan memilih berhati-hati 
bertindak agar mereka tidak melakukan kesalahn. Di samping itu, daya Tarik lain yang ditawarkan massuru' adalah relasi dan kehidupan kembali normal setelah pihakpihak yang berkonflik duduk bersama menyelesaikan masalah. Setelah pelaku memberikan korban pendamaian, maka tidak ada alasan mengingat dan mempertahankan kesalahan masa lampau, apalagi mendendam kepada pelaku kesalahan.

Berdasarkan uraian ini dapat dikatakan massuru' adalah cara memperbaiki kesalahan melalui pertobatan dan pengampunan salah. Kajian ini bermaksud memaparkan tradisi massuru,' serta mengkaji apakah tradisi tersebut dapat digunakan dalam praktik pertobatan (pengakuan dosa) di gereja? Untuk menjawab tujuan penelitian, maka saya menggunakan penelitian eksplanasi dalam arti menjelaskan kedua model dengan menggunakan kajian kepustakaan, mendialogkannya dengan pengamatan di lapangan, baik tentang pelaksanaan massuru' pada tradisi Toraja maupun dampak akta pengakuan dosa dalam kehidupan bergereja.

\section{B. Tradisi Massuru'}

Dalam budaya Toraja dikenal Aluk sola Pemali (AsP). Aluk merupakan adat istiadat dan kepercayaan, ${ }^{1}$ sedangkan pemali terdiri atas berbagai pantangan di mana pelanggaran, dipercaya mendatangkan hal buruk bagi semua masyarakat. AsP mengandung nilai-nilai moral yang menolong masyarakat menjaga relasi dengan Puang Matua, para dewa, sesama manusia maupun alam. Pelanggaran terhadap $A s P$ dipercaya dapat membangkitkan murka dari mereka.

Paham religius tradisional di Toraja percaya bahwa pelanggaran pribadi berdampak kolektif. Jadi tidak mengherankan apabila berbagai pelanggaran seringkali menimbulkan ketegangan di masyarakat. Pelanggaran dianggap mengancam kehidupan masyarakat dan menciptakan kondisi ketidakpastian, ketakutan atas bencana dan sebagainya. Fenomena-fenomena alam dipandang sebagai salah satu bentuk hukuman dari yang ilahi. Bencana alam, gagal panen dan sebagainya dipercaya sebagai tanda adanya pelanggaran dalam masyarakat. Demikian halnya ketika seseorang tiba-tiba mengalami sakit keras tanpa diketahui asal-usulnya.

Ancaman mendorong masyarakat membawa persoalan-persoalan yang dihadapi ke ranah publik. Mereka berembuk serta memeriksa jenis perkara, lalu menyelesaikannya dengan baik. Penyelesaian seperti itu diyakini meminimalisir ruang-ruang yang memperkeruh suasana.

Setidaknya desakan untuk menyelesaikan masalah dipengaruhi oleh tiga hal: Pertama, pandangan tradisional orang Toraja tentang hidup. Kehidupan di dunia hanya sementara, oleh sebab itu semua orang harus mengusahakan kehidupan abadi yakni mencapai tahap membali puang (kembali ke dewa). Tahap tersebut dapat dicapai apabila seseorang didukung oleh pencapaian atau kesejahteraannya di dunia. Harta miliknya di dunia yang disimbolkan oleh hewan korban dalam ritus kematian diyakini menjadi bekalnya selama dalam perjalanan mencapai dunia seberang. Ketika yang bersangkutan maupun orang lain melakukan kesalahan, maka kehidupan atau usaha mendapatkan kepercayaan mengalami hambatan bahkan berhenti. Itu sebabnya hambatan harus segera diselesaikan agar kehidupan kembali mengalir.

${ }^{1}$ Dalam konteksnya aslinya disebut aluk to dolo. Kini istilah itu berkembang seperti aluk sarani (agama Nasrani/ Kristen), aluk Islam (agama Islam). Istilah itu bebas digunakan oleh para penuturnya, dan disesuaikan dengan konteks agama yang sedang di cerita. 
Kedua, manusia Toraja memahami bahwa dunia berada dalam kuasa Puang Matua bersama dewa-dewa yang wilayah kekuasaannya lebih kecil. Segala sesuatu yang digunakan untuk kesejahteraan, hanya dipinjamkan oleh mereka. Atas dasar itu, setiap cara berpikir, merasa, dan bertindak harus dilakukan secara bertanggungjawab. Manusia tidak boleh merusak keseimbangan tatanan kosmis demi kepentingannya semata.

Ketiga, penerima sanksi tidak ditentukan berdasarkan keterlibatannya pada kasus. Banyak kasus baru ketahuan setelah muncul bencana, lalu mereka mulai mencari jenis pelanggaran yang terjadi. Terlepas dari ketidaktahuan, paham kolektifitas yang berkembang, membentuk persepsi bahwa hukuman merupakan hambatan terhadap kehidupan bersama. Ketika seorang mengalami kesusahan, maka anggota masyarakat turut merasakan, demikian sebaliknya. Ketika seseorang melakukan kesalahan, maka yang lain turut bersalah.

Massuru' sebagai proses pengakuan salah mengarah pada pemberian sanksi entah pelaku (kasus tunggal) maupun kepada dua pihak yang bertikai. Namun massuru' tidak dimaknai sebagai penghakiman. Pemberiaan hukuman atau sanksi dalam rangka memperbaiki kehidupan. Kesalahan menyebabkan masyarakat menjalani hidup yang tidak normal. Hambatan itulah yang hendak dibersihkan, diperbaiki supaya berkat kehidupan mengalir dengan baik.

Dengan melaksanakan sanksi yang ditetapkan, pelaku memperoleh pengampunan. Baik perdamaian dengan Puang Matua, para dewa, sesama manusia dan alam semesta. Bagi orang Toraja, perdamaian merupakan syarat bagi terwujudnya kesejahteraan. Pandangan ini diterima sebagai salah satu falsafah hidup. Menurut Th. Kobong, dkk, demi perdamaian orang Toraja rela mengorbankan nilainilai yang lain. Kebenaran dan keadilan bisa dikorbankan demi kedamaian dan kerukunan, bukan hanya antar pihak yang bersengketa tetapi juga persekutuan yang lebih besar. ${ }^{2}$ Dalam massuru' kebenaran dan keadilan ditempatkan sebagai unsur hakiki dari pengampunan salah dan perdamaian.

Berdasarkan kebiasaan, orang yang mengetahui bahwa telah terjadi kesalahan, melapor kepada tokoh-tokoh masyarakat (hakim pendamai) agar mengenai jenis perkara dan harapan agat kasus boleh selesai. Cara tersebut sangat wajar, karena jarang ada pelaku yang mau segera mengakui kesalahannya.

Tidak boleh ada penghakiman sepihak meskipun latar belakang kasus sudah diketahui. Misalnya pengeseran batas tanah, pencemaran nama baik ataupun kasus hamil di luar nikah. Main hakim sendiri dapat menimbulkan kesalahan baru. Setiap kesalahan harus diselesaikan dalam pertemuan keluarga dan musyawarah. Pesertanya dapat sebatas anggota keluarga maupun melibatkan tokoh-tokoh masyarakat. Dalam pertemuan para pelaku diberi kesempatan mengemukakan alasan serta mengutarakan kesanggupan melaksanakan sanksi.

Nilai kemanusiaan dijunjung tinggi. Pelaku yang berasal dari keluarga miskin, tidak dipaksa membawa korban pendamaian melampaui batas kemampuannya. Sanksi selalu dipertimbangkan dengan baik oleh para tua-tua yang hadir dalam pertemuan. Hukuman yang melampaui kemampuan, justru akan menyengsarakan. Kesengsaraan merupakan wujud pelanggaran terhadap harkat kemanusiaan. Jika itu yang dilakukan, maka perhatian masyarakat teralih pada usaha menyelesaikan kasus baru yang muncul.

${ }^{2}$ Th. Kobong, dkk. Manusia Toraja: Dari mana -Bagaimana - Kemana (Toraja: ITGT, 1983), 10. 
Faktor lain yang turut dipertimbangkan, yakni musyawarah menolong semua pihak mengetahui jenis perkara secara jelas serta mengetahui pihak-pihak yang terlibat. Misalnya kasus pertikaian, jika semua pihak bersalah, maka semua dijatuhi sanksi sesuai tingkat kesalahannya. Hewan korban yang dibawa tidak diberikan secara terpisah, satu ekor hewan korban ditanggung bersama oleh pihak yang bersalah sesuai kesalahan dan taksiran sanksi yang harus ditanggung masing-masing pihak. Pengecualian berlaku apabila pihak-pihak yang bersalah berbeda agama karena ritus disesuaikan dengan ajaran masing-masing agama.

Pertemuan atau musyawarah merupakan cara yang tepat menyelesaikan masalah. Musyawarah mencegah ketidakadilan saat memutuskan sanksi. Musyawarah penting bagi kehidupan masyarakat, sebagaimana diungkapkan oleh John Liku Ada' bahwa orang Toraja tidak boleh tergesa-gesa menghakimi orang lain, hak-hak mereka harus diperhatikan sebagaimana ungkapan tallungbongipiki' lan tambukna tau ta mane dadi (butuh waktu tiga malam dalam kandungan baru seseorang lahir). Selanjutnya, orang yang bersalah tidak pantas dikritik secara terbuka tae'na ma'din untossok matanna bale (harfiah: tidak boleh menusuk mata ikan). Tae'na dibatangdallei tu tau (seseorang tidak boleh ditelanjangi seperti jagung). Tae'na dipopa' kambelang tu kada (setiap perkataan tidak boleh diungkap secara terang-terangan). ${ }^{3}$

Tampak orang Toraja menjaga solidaritas dengan membudayakan sikap saling menghargai. Sekalipun seseorang pasti bersalah, teguran terbuka tidak perlu dilakukan, sebaliknya harus mencari cara yang lebih halus untuk menegurnya. Orang yang bersalah tetap harus dihargai perasaannya. Teguran terbuka hanya mempermalukan mereka, sehingga memunculkan respon negatif.

Musyawarah dalam massuru' dipimpin oleh tua-tua kampung. Mereka yang dituakan harus memenuhi kritetia berupa memiliki pengetahuan mengenai adat istiadat, bijaksana serta mampu bersikap adil. Syarat tersebut menjadi jaminan bahwa kelak keputusan benar-benar objektif. Tahap pemeriksaan disebut massalusalu (mengusut dosa). Kesalahan dan pelanggaran dapat dihapuskan dengan membawa persembahan korban, sebagai tanda pembersihan, penyucian (pengampunan salah). Sesuatu dikatakan baik apabila sikap dan tindakannya sesuai $A s P$, sedangkan kesalahan adalah sikap dan tindakan yang berlawanan dengan $A s P .{ }^{4}$

Ritus mempersembahkan korban pendamaian biasanya menjadi puncak dari massuru.' Meski demikian, pengakuan salah tidak selalu berakhir dengan pengorbanan hewan. Untuk pelanggaran terhadap $A s P$ kesalahan dapat diampuni cukup dengan menuntut mereka mengaku dan berjanji memperbaiki diri.

Ritus persembahan korban antara lain: praktik marambui langi' (harfiah: mengasapi langit) yakni mencurahkan darah ke tanah sekaligus menaikkan korban bakaran. Bau-bauan dari hewan korban bermakna kampung sedang dibersihkan dari berbagai efek buruk kesalahan. Korban juga menyimbolkan pengakuan salah dan perdamaian dengan Puang Matua, para dewa maupun alam semesta. Korban menertibkan kembali kampung (wilayah) serta menghindarkan penduduk dari

${ }^{3}$ John Liku Ada'. “Towards A Spirituality Of Solidarity: A Study of Sa'dan -Torajan Solidarity in the Light of Gaudium et Spes, with a View to an Inculturated Authentic Christian Sipritiality of Solidarity" (Disertasi Dr., Pontificiae Universitatis Gregoriana., 1986), 164.

${ }^{4}$ Kobong, dkk. Manusia Toraja, 42. 
malapetaka. Orang Toraja percaya bahwa dengan marambui langi,' penyakit dan bencana perlahan akan berakhir. ${ }^{5}$

\section{Pandangan Teologi Kristen Tentang Pertobatan}

Injil-injil sinoptik membingkai kisahnya dengan seruan pertobatan dan pengampunan dosa. Pertobatan ditempatkan di awal (sisi terluar) sedangkan bagian akhir (sisi terdalam) adalah pengampunan dosa. Seruan pertobatan dimulai dengan warta Yohanes Pembaptis sedangkan pengampunan dosa ditegaskan dalam peristiwa sengsara, kematian dan kebangkitan Yesus Kristus. Para penulis Injil menggunakan tema tersebut untuk membina kehidupan jemaat yang menjadi tujuan penulisannya. Misalnya, Injil Matius yang ditujukan kepada komunitas Israel yang baru atau umat Yesus Kristus, berasal dari komunitas Yahudi dan campuran non Yahudi. ${ }^{6}$

Seruan pertobatan dari Yohanes Pembaptis pertama-tama dikaitkan dengan sikap komunitas Esseni (Qumran) di mana ia diperkirakan menjadi anggotanya. Kelompok esseni mengasingkan diri dari hiruk-pikuk dunia sebagai cara menghindar dari perbuatan dosa. Bagi mereka dunia bergerak pada arah yang berlawanan dengan kehendak Allah. Memang manusia berusaha menaati hukum-hukum Tuhan, namun terjadi mereka memperjuangkan kepentingan pribadi. Yohanes Pembaptis berbeda dengan para pemuka agama Yahudi dimasanya. Para pemuka agama menilai, membatasi dan menyisihkan orang-orang yang dianggap berdosa.

Ketaatan pada hukum taurat tidak cukup, manusia harus berbalik kepada Allah. Bagi Yohanes Pembaptis, pertobatan ditunjukkan melalui kesediaan mengaku dosa dan memberi diri dibaptis (Mrk. 1:4; Mat. 3: 2,6; Luk. 3;3). Memang kata bertobat yang digunakan tetap menunjukkan keputusan berada pada mereka yang dituju oleh seruan (pelaku), bukan karena orang lain mendesaknya agar mengaku salah. Pertobatan tampak melalui kesediaan berbalik dari salah lalu memberi diri untuk melakukan yang terbaik.

Orang yang bertobat harus menunjukkan hidup yang berkenan kepada Allah melalui sikap dan tindakan, antara lain: peduli kepada sesama yang menderita, berlaku adil, berhenti memeras memulai hidup secukupnya, dsb (Luk. 3:7-14). Konsep pertobatan sudah terdengar dalam seruan para nabi dalam Perjanjian Lama, di mana mereka meminta umat Israel berhenti memberontak terhadap Allah dengan cara kembali menaati perjanjian dengan-Nya. ${ }^{7}$ Untuk kepentingan ini beberapa kali terjadi pembaruan perjanjian antara umat dengan Tuhan.

Pada masa Yesus, konsep tahir dan tidak tahir (najis) sedang menguat dan menjadi tolok ukur apakah seseorang hidup sebagai orang benar maupun berdosa? Ketahiran berhubungan dengan status sosial, ekonomi dan politik seseorang. Dari segi sosial, seseorang yang terlahir dari kelompok imam dan orang-orang Yahudi yang bertobat digolongkan sebagai orang tahir (suci). Sementara itu, mereka yang tergolong najis yakni anak-anak haram, orang yang lama sakit dan tidak utuh secara jasmani, para pelanggar kaidah moral yakni kelompok masyarakat yang disisihkan seperti pemungut cukai, kaum miskin dan lemah.

Yesus menawarkan perspektif baru dalam wartaNya tentang Kerajaan Allah. Kerajaan Allah dialami apabila seseorang bertobat dan percaya kepada Injil (Mrk.

\footnotetext{
${ }^{5}$ Kepercayaan tersebut tetap hidup khususnya bagi masyarakat di kampung-kampung Toraja, di mana masih ada penganut aluk to dolo.

${ }^{6}$ Samuel Benyamin Hakh, Ketegaran Menghadapi Krisis Identitas: Suatu Studi Terhadap Silsilah Yesus dan Maknanya Bagi Komunitas Matius (Jakarta: UPI STT Jakarta, 2005), 186.

7 R.T. France, Matthew (Surabaya: Momentum, 2007), 90.
} 
1:14-15, Mat. 4: 7). Pada masa itu dosa dipahami sebagai tindakan yang berlawanan dengan kehendak Allah. Seseorang berdosa karena perbuatannya sendiri maupun akibat ulah orangtuanya.

Kata metanoia dalam Injil Markus menjelaskan bahwa pertobatan menuntut perubahan sikap dan tindakan. Seseorang harus merubah arah hidupnya dari kebinasaan menuju kehidupan kekal. ${ }^{8}$ Perubahan terjadi jikalau pelaku memotivasi diri untuk berubah.

Para ahli agama Yahudi memandang pertobatan dari konsep tahir-najis yang kelihatan, Yesus justru memandang pertobatan dari kedalaman hati. Pertobatan harus dilandasi oleh belarasa. ${ }^{9}$ Dalam arti keinginan merubah diri yang disertai kepedulian kepada sesama. Sikap belarasa dicirikan dengan menghindari sikap angkuh, tidak melakukan diskriminasi dan tidak hidup dalam ketaatan semu pada aturan-aturan. Lain kata, pertobatan bukan sekedar praktek melainkan pada aspek perasaan yang mendorong seseorang bertindak.

Yesus menegaskan bahwa setiap orang yang mengikut Dia perlu bertobat dan menerima warta-Nya tentang Kerajaan Allah lalu memulai kehidupan baru yang dibimbing oleh Tuhan. ${ }^{10}$ Kerajaan Allah yang diwartakan Yesus berbeda dengan pemerintahan dunia. Kerajaan Allah merupakan sebuah pemerintahan yang dikendalikan oleh Allah. Kerajaan Allah mengungkapkan otoritas Yesus, kuasanya dalam mengusir setan, menyembuhkan orang sakit, membangkitkan orang mati, memberikan keselamatan dan kehidupan kekal. ${ }^{11}$ Berdasarkan unsur-unsur tersebut, sangat jelas sikap Yesus dalam melawan kuasa dosa (kematian) yang mengukung manusia. Hal itu tidak hanya dialami oleh orang-orang yang menderita, tetapi juga orang-orang yang dengan sengaja menekan kelompok orang berdosa yakni para pemuka agama yang berasal dari golongan imam dan ahli-ahli Taurat, bahkan orangorang Farisi termasuk kategori ini. Kelompok terakhir dapat dikategorikan orang berdosa apabila merujuk uraian Samuel Benyamin Hakh mengenai kekuasaan setan. Menurutnya, setan menguasai orang yang melakukan kejahatan, bahwa kekuasaan setan tampak pada mereka yang hidup dalam kejahatan, yang memutarbalikkan kebenaran serta yang selalu berseru kepada Allah tetapi tidak melakukan kehendakNya. ${ }^{12}$

Seorang petobat perlu mewujudkan warta Yesus tentang Kerajaan Allah seperti tersimpul dalam Injil Lukas yakni menyatakan kabar baik dalam dunia, menyatakan pembebasan bagi yang tertawan dan tertindas, serta menolong orang yang sakit (Luk 4:18-19). Pertobatan merupakan perubahan diri, di mana manusia meninggalkan dosa lalu bertindak sesuai dengan kehendak Allah yakni mewujudkan damai sejahtera Allah. ${ }^{13}$ Jadi hidup baru dalam Kerajaan Allah adalah hidup yang berbalik dari dosa.

\section{Pengampunan: Hubungan Baru}

Dari uraian di atas, dosa terjadi dalam relasi sosial. Pada satu sisi klaim-klaim para pemuka agama tentang tahir atau kesucian menjebak diri sendiri sebagai pelaku

\footnotetext{
8 Samuel Benyamin Hakh, Pemberitaan Tentang Yesus: Menurut Injil-injil Sinoptik (Jakarta: Jurnal Info Media, 2008), 26.

${ }_{9}^{9}$ Marcus J Borg, Kali Pertama Jumpa Yesus Kembali: Yesus Sejarah dan Hakikat Iman Kristen Masa Kini, Terjemahan Ioanes Rakhmat (Jakarta: BPK Gunung Mulia, 2000), 56-70.

10 Martin Harun, Markus: Injil yang Belum Selesai (Yogyakarta: Kanisius, 2015), 46-47.

11 R. Alan Cole, Mark (Surabaya: Momentum, 2007), 67.

12 Samuel Benyamin Hakh, Pemberitaan Tentang Yesus, 52.

13 B.F. Drewes, Satu Injil Tiga Pekabar (Jakarta: BPK Gunung Mulia, 2016), 119-121.
} 
dosa. Konsep itu merujuk pada substansi klaim yang bermakna memertahankan status quo. Klaim mereka sesungguhnya bernuansa politis karena menjaga hegemoni pemuka agama, belum lagi berkembang sikap yang melihat status atau kedudukan sosial sebagai tolok ukur pergaulan. Sikap-sikap demikian, melanggengkan tindakan diskriminasi terhadap kaum pendosa. Sikap pemuka agama bertentangan dengan dimensi universalitas Kerajaan Allah. Kerajaan Allah untuk semua orang, di mana Yesus berulang kali menjelaskan maksud kedatangan-Nya yakni menyelamatkan orang berdosa supaya mereka pun mendapat kesempatan mengalami damai sejahtera dalam pemerintahan Allah.

Konsep salah dan dosa sangat erat bahkan bertumpang tindih. Kedekatannya muncul dalam formulasi doa Bapa kami sebagaimana diajarkan oleh Yesus (Mat. 6:913; Luk. 11:2-4). Kata "ampunilah kami atas kesalahan kami, seperti kami juga mengampuni orang yang bersalah kepada kami" mendapat penjelasan dalam teks selanjutnya "karena jikalau kamu mengampuni kesalahan orang, Bapamu yang di sorga akan mengampuni kamu juga ..." (Mat. 6:14-15). Teks mengambarkan bahwa seseorang berhak mendapat pengampunan, karena ia telah mengampuni kesalahan orang lain. Permintaan pengampunan juga menunjukkan kesadaran batin bahwa yang bersangkutan bersalah di hadapan Allah. Hemat saya, pengakuan itu memberi gambaran bahwa pengakuan salah dan pengampunan harus dimulai dari diri sendiri. Seseorang harus mampu mengendalikan dirinya, agar dapat membuka diri mengampuni orang lain. Injil Sinoptik memperlihatkan bahwa model pengampunan itu yang disempurnakan oleh Yesus melalui peristiwa sengsara, kematian dan kebangkitan-Nya.

Melakukan kesalahan berarti berdosa kepada Allah. Dikatakan demikian, sebab setiap kesalahan merupakan perlawanan terhadap kehendak Allah, di mana Ia menuntut manusia menyatakan kebenaran dan kasih. Di beberapa bagian teks Alkitab, kesalahan menimbulkan rasa malu di hadapan Allah. Dengan menjelaskan teori Thomas Schiirmacher, Binsar Jonathan Pakpahan menegaskan bahwa orientasi malu dan salah di Alkitab saling melengkapi. Malu merupakan ekspresi dari perasaan bersalah, dan seseorang yang ketahuan bersalah akan dipermalukan. Malu muncul karena ada kerusakan relasi yang diakibatkan oleh pelanggaran, sehingga hukuman terberat atas pelanggaran adalah pemutusan hubungan atau pengasingan. ${ }^{14}$ Namun perasaan malu seakan hilang dari para pemuka agama Yahudi, mereka menutupi kesalahannya justru dengan menghakimi orang lain dengan menyatakan bahwa orang lain berdosa.

Kesalahan diatasi dengan pengampunan dan menghindari keinginan menuntut balas. Kesalahan yang dibalas dengan dendam hanya menciptakan dosa berantai bagi manusia. Dalam arti bahwa dendam menyebabkan seseorang melakukan banyak kesalahan. Kesalahan hanya dapat diatasi melalui kerelaaan mengampuni. ${ }^{15}$ Menurut Martin Harun, pengampunan ditandai dengan pulihnya relasi Bapa dengan anakanakNya. Dalam pengampunan manusia mengalami kesembuhan yang sesungguhnya. Bersamaan dengan itu, harus ada pemisahan antara dosa dan penyakit. Penyakit tidak mutlak menandakan bahwa seseorang berdosa, walaupun tidak dipungkiri bahwa si sakit pernah berdosa kepada Allah. ${ }^{16}$

14 Binsar Jonathan Pakpahan, Mengembalikan Malu Spiritual: The Power of Shame (Jakarta: BPK Gunung Mulia, 2017), 74-78.

15 Joseph Ratzinger, Yesus dari Nazareth (Jakarta: Gramedia, 2008), 173.

16 Harun, Markus: Injil, 72. 
Pengampunan sejati ditunjukkan Allah dengan tidak menuntut balas atas kesalahan manusia. Ia menyatakan pengampunan dengan turun tangan langsung mengorbankan anak-Nya untuk mendamaikan manusia dengan diri-Nya. Dalam kisah sengsara Ia menempatkan anak-Nya sebagai wakil orang berdosa. Yesus memperlihatkan model ketaatan yang harus dilakukan oleh orang percaya, yang mana harus menyadari kesalahan dan menyerahkan diri dalam rencana Allah. Bukan membela diri, tetapi memohon pengampunan dari Allah sembari mengampuni orang lain yang melakukan kesalahan kepadanya (Luk 23:34). Membadingkan teks Lukas dan Markus. Tampak bahwa seruan "Ya Bapa, ampunilah mereka..." berasal dari bahan lain. Perhatian Markus lebih pada gambaran Yesus sebagai Raja Orang Yahudi (Mrk. 15:26), sementara Lukas memperlihatkan kata-kata itu sangat penting, bahkan mungkin menerangkan alasan kehadiran-Nya di dunia. Gambaran Yesus sebagai Raja kurang ditekankan bahkan mungkin dapat dikatakan sebagai kata keterangan tentang mengapa Ia berhak mengampuni. Warta pengampunan dalam Lukas menggambarkan mereka yang tinggal atau mengalami Kerajaan Allah adalah mereka yang menerima pengampunan dari-Nya.

Oleh karena itu, penting mempertimbangkan tiga model pendamaian dalam sejarah gereja, sebagaimana klasifikasi Gustav Aulen seorang teolog Swedia, antara lain: model Kristus pemenang, pengembalian dan pengaruh moral. ${ }^{17}$ Model pertama menggambarkan kemenangan Kristus dari peperangan kosmis melawan setan, sedangkan dua model terakhir lebih dekat dengan ketaatan pada aturan-aturan. Ketidaktaatan menyebabkan manusia berhutang kepada Allah. Orang-orang Yahudi biasanya menggunakan kata ofeileimata yang berarti hutang dalam doa-doanya. Kata ini menerangkan peristiwa pengampunan dosa. Mereka menggunakannya untuk menunjukkan ketidaktaatan manusia kepada Tuhan-nya. ${ }^{18}$ Serentak dengan itu, memohon pengampunan dan komitmen janji setia kepada Allah. Hanya saja model kedua meninggalkan pertanyaan mengenai anugerah Allah? Teologi Kristen menerima paham bahwa pengampunan merupakan anugerah Allah yang telah berinisiatif membuka diri dan berdamai dengan manusia.

Yesus menguraikan tema pengampunan dalam beberapa kisah, antara lain penyembuhan orang lumpuh (Mat. 9:1-8; bdk Luk.5: 20), Yesus diurapi oleh perempuan berdosa (Luk. 7:36-50) dan sebagainya. Pada kisah orang lumpuh, Yesus mendahului dan mengakhiri penyembuhan dengan menegaskan tentang pengampunan dosa. Menurut de Heer, dalam kisah tersebut, Yesus menolak paham Yahudi yang menghubungkan antara penyakit dan dosa, sekalipun ia tidak memungkiri bahwa si lumpuh memang pernah berbuat dosa. Untuk mendukung argumennya, ia mengemukan tiga alasan: (1) Mungkin si lumpuh memang pernah melakukan pelanggaran besar kepada Tuhan. (2) Status si lumpuh sama dengan orang berdosa lain yang mengharapkan pengampunan dari Tuhan. (3) Hubungan manusia dengan Tuhan harus dipulihkan, supaya tidak berdampak negatif terhadap roh dan tubuh. ${ }^{19}$ Perspektif lain ditampilkan penulis Injil Lukas, dibalik kesembuhan dan pengampunan yang dialami oleh si lumpuh, penulis hendak menampilkan iman dari teman-temannya, yang berani membawa si lumpuh kepada Yesus. ${ }^{20}$ Berdasarkan

${ }^{17}$ Joas Adiprasetya, Berdamai Dengan Salib: Membedah Ioanes Rakhmat dan Menyapa Umat (Jakarta: Grafika Kreasindo-STT Jakarta, 2010), 27-48.

18 J.J. de Heer, Injil Matius Pasal 1-22 (Jakarta: BPK Gunung Mulia, 2008), 104.

19 Ibid, 56-157.

20 Eko Riyadi, Lukas; Sungguh, Orang ini adalah Orang Benar! (Yogyakarta: Kanisius, 2011), 84. 
kisah, jelas bahwa pengampunan dapat dialami seorang yang bersalah, jika ia diarahkan orang sekitarnya untuk menyerahkan diri kepada Allah.

Pada kisah Yesus diurapi oleh perempuan berdosa, alur cerita bermula ketika Yesus berada di rumah Simon orang Farisi. Ia bagian dari kelompok masyarakat yang berusaha menjaga kesucian hidupnya dengan menutup pergaulan dengan orangorang berdosa. Yesus menunjukkan citra orang yang lebih baik (benar) dari orang lain tidak menjamin seseorang mendapat pengampunan lebih besar. Pengampunan dosa menuntut penyesalan mendalam dan perbuatan kasih sebanyak-banyaknya (Luk. 7:44, 47).

Ajaran tentang pengampunan dosa, makin jelas dalam peristiwa perjamuan malam (Mat. 26:26-29; Mrk. 14:22-25; Luk. 22:14-23). Pada peristiwa perjamuan malam Yesus menjelaskan tentang kisah sengsara yang akan dilalui. Yesus menjadi korban pendamaian, dengan menyerahkan tubuh-Nya, menumpahkan darah-Nya demi membebaskan manusia dari kuasa dosa. Sebagai korban pendamaian, Yesus memungkinkan semua orang mengalami pengampunan dosa dan memasuki hubungan yang baru dengan Allah. Kematian Yesus menyatakan belas kasihan dan kasih setia Bapa kepada manusia yang berdosa. ${ }^{21}$ Ketiga Injil Sinoptik menekankan kata perjanjian (Mrk. 14:24; Mat. 26:28; Luk. 22:20). Perjanjian mengingatkan relasi Allah dengan Israel dalam Perjanjian Lama, yang dibarui saat perjamuan malam.

\section{E. Persamaan dan Perbedaan Massuru' dengan Pertobatan}

Massuru' maupun pertobatan dalam Injil bertujuan memulihkan dan menata kembali kehidupan yang rusak akibat kesalahan atau dosa. Manusia dituntut berbalik dari sikap dan tindakan yang menyimpang dari nilai-nilai $A s P$ dan ajaran agama dengan mewujudkan kehidupan yang mengedepankan kebenaran dan keadilan serta nilai-nilai lainnya. Nilai-nilai tersebut mencerminkan kehendak Allah pada manusia.

Baik massuru' dan pertobatan sama-sama menampilkan paham bahwa kesalahan pribadi menyebabkan kehidupan orang lain berada dalam bahaya. Dosa individu dapat berakibat kolektif. Hanya saja dalam pengaruh pemikiran Barat, paham kekristenan mulai dipengaruhi oleh konsep individualis. Di mana hukuman ditanggung oleh yang bersalah. Pemahaman bahwa kesalahan seseorang mengakibatkan kehidupan orang lain ikut terganggu, mulai diabaikan. Melihat uraian tentang pertobatan dalam Injil Sinoptik, pandangan tentang dosa berbeda dengan tradisi Toraja. Pada tradisi Toraja, kesalahan satu orang menyebabkan semua orang mengalami ancaman yang sama. Jika berangkat dari tradisi Yahudi, memang ada pemahaman bahwa dosa orang tua bisa ditanggung oleh anaknya (Yoh 9:1), tetapi dalam uraian Injil Sinoptik semua berdosa karena alasan yang berbeda. Orang benar yang menghakimi orang berdosa lewat sikap dan tindakannya, juga masuk dalam kategori berdosa. Mereka berdosa karena membenarkan diri sendiri.

Baik massuru' dan pertobatan memiliki kemiripan pola, yakni: mengaku salah atau dosa - pengampunan - pendamaian. Perbedaannya ada pada inisiatif untuk mengaku salah. Dalam kebiasaan orang Toraja, pengakuan salah terjadi jikalau orangorang yang mengetahui kasus sepakat untuk membawa permasalahan si pelanggar ke dalam pertemuan lalu mendorongnya untuk mengaku salah. Sebaliknya dalam Injil sinoptik, perintah Yesus tentang pertobatan menuntut orang-orang berdosa mengambil sikap melanjutkan kesalahannya atau berhenti dari kesalahan dengan bersedia mengaku dosa di hadapan Allah.

${ }^{21}$ Harun, Markus: Injil, 240. 
Pendamaian merupakan tujuan akhir yang ingin dicapai dan diyakini sebagai keadaan di mana kehidupan mengalir kembali. Kehidupan yang didalamnya tercipta damai sejahtera karena pihak bersalah dan yang dirugikan dapat saling menerima satu dengan yang lain. Entah dalam relasi Allah dan manusia atau dalam relasi manusia dengan sesamannya maupun relasi manusia dengan ciptaan lain.

Perbedaan mencolok terjadi dalam cara menyasar perubahan perilaku. Pertobatan dalam massuru' menyelesaikan masalah dengan menonjolkan aspek yang kelihatan. Sekalipun dilakukan pemeriksaan salah secara objektif, tetapi hal yang ditekankan adalah aspek perbuatan, di mana seseorang tidak mengulangi kesalahan yang sama. Sebaliknya dalam Injil sinoptik pertobatan menyusur pertobatan batin, di mana ketika orang meresapi atau menjiwai kehendak Allah, maka mereka akan menampakkan pemerintahan Allah dengan berbuat baik. Kalaupun sekarang massuru' seakan memberi perubahan lebih besar dari sekedar pengakuan dosa dalam gereja, hal itu dipengaruhi oleh corak hidup manusia yang mengukur perubahan atau pertobatan dari aspek kelihatan dibanding perubahan dari dalam.

Mengenai implementasi dari kerangka kerja tersebut, massuru' menggunakan model yang mirip dengan praktik kekristenan bahwa seseorang tidak diadili dan dinyatakan bersalah tanpa melalui proses yang jelas. Massuru' melewati tahap memeriksa kasus, bahkan membicarakan jenis hukuman supaya tidak melampaui kemampuan pihak terhukum. Tahapan tersebut mendekati konsep kekristenan tentang pendampingan pastoral terhadap orang yang berdosa. Demikian juga untuk kasus-kasus berkenaan dalam kesalahan membangun relasi satu dengan yang lain sehingga menyebabkan konflik. Massuru' dan pertobatan berusaha mendalami kasus secara jelas, meskipun secara kasat mata diketahui siapa yang benar dan salah, tetapi kedua pihak harus tetap dipertemukan dalam rangka mengurai kasus seobjektif mungkin. Yang benar tidak diizinkan main hakim sendiri dan menekan yang salah, Yang benar pun diarahkan untuk membuka diri mengampuni orang yang bersalah kepadanya.

Perbedaan mencolok terjadi dalam konsep korban pendamaian. Makna korban pendamaian dalam massuru' lebih dekat dengan tradisi Perjanjian Lama yang mana setiap korban bermaksud menyelesaikan sebuah pelanggaran (alasan diadakannya ritus korban). Maknanya berbeda dengan pengorbanan Yesus Kristus, korban pendamaian yang berlaku sekali untuk selamanya. Yang berulang adalah manusia diberi kesempatan untuk terus-menerus mengaku dosa dan berkomitmen hidup baru di hadapan-Nya.

Berdasarkan uraian-uraian di atas dapatkah massuru' menjadi pilihan alternatif pengakuan dosa bagi umat Kristen? Menurut hemat saya, jika yang menjadi patokan adalah tataran makna dan tujuan akhir yakni pertobatan yang mengarah pada perwujudan perdamaian holistik, maka massuru' dapat digunakan, baik sebagai model akta pengakuan dosa anggota jemaat, ataupun sebagai model pastoral tobat yang sifatnya eksklusif. Dalam arti pada tataran kasus yang dirahasiakan kepada orang banyak atau anggota jemaat secara umum karena dipandang dapat menambah beban dan membuat yang bersangkutan menanggung malu dalam jangka waktu yang cukup lama.

Hal yang perlu diluruskan sejak awal yakni makna korban pendamaian di tahap akhir massuru.' Tentu saja mayoritas masyarakat yang melestarikan budaya ini menolak jika korban pendamaian ditiadakan. Peniadaan dinilai menghilangkan atau mengerus kekhasan jati diri lokal. Untuk mengatasi kesulitan tersebut, maka praktek korban dapat dipertahankan tetapi maknanya dibatasi hanya sebagai tanda atau 
simbol pengakuan salah. Korban dimaknai sebagai kesediaan berkomitmen, seperti halnya tradisi-tradisi lain yang menggunakan darah korban sebagai ikatan perjanjian. Tetapi bukan korban yang mendamaikan atau mengampuni salah, sebab dalam kekristenan hanya Yesus Kristus yang memainkan peran tersebut secara holistik. Yesus Kristus menempatkan diri sebagai wakil manusia yang menyerahkan diri di hadapan Allah, mengaku dosa serta menanggung akibat dosa. Dengan menjadi korban pendamaian Yesus, memberikan kesempatan kepada manusia mengalami pengampunan dosa dari-Nya.

\section{F. Kesimpulan}

Massuru' dalam tradisi Toraja dan pertobatan dalam Injil sinoptik sama-sama dapat dipergunakan untuk memperbaiki kehidupan orang yang bersalah dan berdosa. Keduanya menekankan pengampunan sekalipun menggunakan pendekatan yang berbeda. Jika orientasi gereja menuntun jemaat untuk hidup sesuai dengan kehendak Allah tanpa mengabaikan otoritas-Nya sebagai sumber utama pendamaian, maka yang dapat dikatakan yakni massuru' dapat digunakan sebatas tata cara penyelesaian masalah. Perubahan-perubahan penting harus dilakukan dengan memasukkan nilai-nilai iman Kristen tentang perdamaian ke dalam tata cara penyelesaian massuru.' Hal itu bertujuan menghindari pertentangan antara praktik massuru' dengan iman Kristen. Namun tidak berarti nilai-nilai kebajikan yang terkadung di dalamnya, yang dihidupi dan dijadikan oleh orang Toraja sebagai bahan acuan menyelesaikan salah ditiadakan. Nilai-nilai tersebut dapat diakomodir dengan metransformasi maupun memperteguhnya sesuai makna pertobatan sebagaimana terurai dalam Injil.

\section{Daftar Pustaka}

Ada', Jhon Liku., "Towards A Spirituality Of Solidarity: A Study of Sa'dan -Torajan Solidarity in the Light of Gaudium et Spes, with a View to an Inculturated Authentic Christian Sipritiality of Solidarity." Disertasi Dr., Pontificiae Universitatis Gregoriana, 1986.

Adiprasetya, Joas. Berdamai Dengan Salib: Membedah Ioanes Rakhmat dan Menyapa Umat. Jakarta: Grafika Kreasindo-STT Jakarta, 2010.

Borg, Marcus J. Kali Pertama Jumpa Yesus Kembali: Yesus Sejarah dan Hakikat Iman Kristen Masa Kini, Terjemahan Ioanes Rakhmat, Jakarta: BPK Gunung Mulia, 2000.

Cole, R. Alan. Mark. Surabaya: Momentum, 2007.

De Heer, J.J. Injil Matius Pasal 1-22. Jakarta: BPK Gunung Mulia, 2008.

Drewes, B.F. Satu Injil Tiga Pekabar. Jakarta: BPK Gunung Mulia, 2016.

France, R.T. Matthew. Surabaya: Momentum, 2007.

Hakh, Samuel Benyamin Hakh. Pemberitaan Tentang Yesus: Menurut Injil-injil Sinoptik. Jakarta: Jurnal Info Media, 2008.

Hakh, Samuel Benyamin. Ketegaran Menghadapi Krisis Identitas: Suatu Studi Terhadap Silsilah Yesus dan Maknanya Bagi Komunitas Matius. Jakarta: UPI STT Jakarta, 2005.

Harun, Martin. Markus: Injil yang Belum Selesai, Yogyakarta: Kanisius, 2015. 
Kobong, Th., dkk. Manusia Toraja: Dari mana -Bagaimana - Kemana. Toraja: ITGT, 1983.

Pakpahan, Binsar Jonathan. Mengembalikan Malu Spiritual: The Power of Shame. Jakarta: BPK Gunung Mulia, 2017.

Ratzinger, Joseph. Yesus dari Nazareth. Jakarta: Gramedia, 2008.

Riyadi, Eko. Lukas; Sungguh, Orang ini adalah Orang Benar! Yogyakarta: Kanisius, 2011. 